\title{
THE CHALLENGES OF ISLAMIC ECONOMIC LAW IN THE INDUSTRIAL REVOLUTION
}

\author{
Supardin \\ UIN Alauddin Makassar, Indonesia \\ Email:supardin.pati@uin-alauddin.ac.id
}

Abstract

This paper explains the challenges of Islamic Economic Law (fiqh muamalah) in the industrial revolution 4.0 era. It aims to analyze the role and implementation of Islamic Economic Law in Indonesia. This is a library-based study. The findings show that there is a rapid development in economic sector that shapes the practice of Islamic Economic Law. Despite the rapid global economic development and the increasing public interest towards the Islamic banking and economy, the Islamic economic Law is facing major problems and challenges. Because of these challenges, the development of the Islamic economic system in Indonesia, in the future, must take further steps or development strategies to implement the Islamic economic system more optimally, such as adaptation to global needs and high competitiveness.

Tulisan ini menjelaskan tentang realitas figh muamalah di era revolusi industri 4.0. Tujuanny a dalah untuk melihat peran dan implementasi fiqh muamalah terhadap kegiatan ekonomi Islam, terutama di Indonesia yang mayoritas penduduknya adalah Muslim. Jenis penelitian yang digunakan adalah penelitian normatif dengan pendekatan penelitian kepustakaan. Penelitian ini dikategorikan sebagai tipe analitik deskriptif, yang mencoba untuk menggambarkan dan memberikan analisis yang komprehensiftentang pengembangan figh muamalah di era modern ini, yang biasa disebut sebagai revolusi industri 4.0. Hasil penelitian ini menunjukkan bahwa ada perkembangan pesat yang terjadi di sektor ekonomi. Namun terlepas dariperkembangan ekonomi global yang cepat dan meningkatny a minat publik terhadap perbankan dan ekonomi Islam, Figh Muamalah menghadapi masalah dan tantangan besar. Karena tantangan ini, pengembangan sistem ekonomi Islam di Indonesia, di masa depan, harus mengambil langkah dan strategi pengembangan untuk mengimplementasikan sistem ekonomi Islam secara lebih optimal, seperti adaptasi terhadap kebutuhan global dan daya saing yang tinggi.

Keywords: Islamic Economic Law; industrial revolution; Islamic law 


\section{Introduction}

The field of Islamic Economic Law (Fiqh muamalah) is a broad field of ijtihad, because Islamic Economic Law concerns human life which has always been developing. Besides, al-Qur'an's argument about maliyah muamalah (wealth of Islamic transaction) is global in nature (kully), not in detail (juz'iy). This global character will make Islamic Economic Law more elastic and flexible in facing the changes and challenges. Islamic Economic Law as a result of developing the human potential in reaching as much as Ilahiyyat values as possible, regarding the rules of human relations (makhluqat). Islamic Economic Law is the science of the law of various activities or transactions carried out by humans in accordance with the set rules in Islam. The legal basis itself comes from propositions such as the Qur'an, the hadith of the Prophet, and ijma.'

The scope of Islamic Economic Law exists in all aspects of human life such as economy, politics, and social aspect. ${ }^{2}$ This Islamic Economic Law is very important for the life of mankind. If we carry it out well, it will create the essential welfare because this law was also created directly by the Almighty God, Allah. It has been proven in the time of the Prophet. First, the friends were able to carry out Islamic Economic Law perfectly based on the guidance of the Prophet thus created prosperity that turned to be the center of world attention. In other words, Islamic Economic Law is flexible and adjustable to the current development, for example in ancient times people traded by barter system. After the discovery of gold and silver, muamalab then continued by no longer using the media of gold and silver, but using a currency that had a value guarantee of gold and silver, instead. ${ }^{3}$

Likewise, in this modern era, the development of modern science and technology has brought major impact on human life, including to the Islamic economic activities commonly referred to Islamic Economic Law. One certain thing is that the Industrial Revolution 4.0 has come in the midst of modern times and it is no longer possible for human beings to avoid. ${ }^{4}$ This process will continue and the millennial generation must try to be selective to prevent the

1 Hendi H Suhendi, Fiqh Muamalah: Membahas Ekonomi Islam Kedudukan Harta, Hak Milik, Jual Beli, Bunga Bank. Dan Riba, Musyarakah, Ijarah, Mudayanah, Koperasi, Asuransi, Etika Bisnis Dan Lain- Lain (Jakarta: PT RajaGranfindo Persada, 2002), 2.

2 Suhendi, 5.

3 Muhammad Syamsudin, "Revolusi Industri 4.0 Dan Perkembangan Akad Muamalah," accessed May 21, 2020, https://islam.nu.or.id/post/read/92425/revolusi-industri-40-dan-perkembangan-akadmuamalah.

4 Hendra Suwardana, "Revolusi Industri 4. 0 Berbasis Revolusi Mental," JATI UNIK : Jurnal Ilmiah Teknik dan Manajemen Industri 1, no. 2 (April 18, 2018): 109, https://doi.org/10.30737/jatiunik.v1i2.117. 
negative impacts. The changing era is the biggest challenge for Muslims or Islamic law scholars, to continue to study and understand Islamic law (fiqh), especially in the field of Islamic Economic Law which is relevant in each period of human life, and in accordance with the Islamic rules listed in the Quran and Hadith. ${ }^{5}$

Based on this phenomenon, today muamalah (transaction) practices especially about the economy will continue to develop. ${ }^{6}$ If previously, muamalah practices were carried out by face-to-face way or directly in the market, but today these practices have developed into indirect markets. wasilah (transaction methods) used is online media and the development of digital technology. Finally, the Industrial Revolution 4.0 is an inevitable. ${ }^{7}$ Therefore, the author is very interested in researching and examining how the reality of Islamic Economic Law in current modern time which is called the era of the industrial revolution 4.0. Based on this background, the formulation of the main problem that arises is "what is the reality of fiqh in the era of the industrial revolution 4.0" which is then limited to several sub-problems: the meaning, scope and legal basis of Islamic economic law, the history of Islamic economic law, and the challenges of Islamic economic law in the industrial revolution era 4.0.

\section{Research Methods}

This research is a normative study, through library research on various documents and related legal literature. The data is processed and analyzed qualitatively. The research data was obtained from secondary data, taken from library materials, including figh books, literature, legislation, official documents, previous researches, articles, magazines, newspapers, and other sources relating to this research. The secondary data is taken from primary legal materials in the form of regulations relating to Islamic Economic Law. This study also aims to illustrate the problem of the reality of Islamic Economic Law in this modern era which is commonly called the industrial revolution 4.0. There have been many new sharia labeled institutions. Thus, it can be seen how far the role of Islamic law in the Islamic economy in today's modern time.

5 Nuha Qonita, "Positioning Islamic Legal Theory in the Development of Islamic Finance," Jurisdictie: Jurnal Hukum Dan Syariah 10, no. 1 (2019): 18, http://dx.doi.org/10.18860/j.v10i1.7034.

6 Khoirul Hidayah, "Model Pembiayaan Pendaftaran Merek Bagi Pengusaha Kecil Menengah Dengan Melalui Akad Bai’ Al Istishna',' Jurisdictie: Jurnal Hukum Dan Syariah 10, no. 2 (2019): 157, http:// dx.doi.org/10.18860/j.v10i2.8303.

7 Soesi Idayanti, Suci Hartati, and Toni Haryadi, "Pembangunan Hukum Bisnis Dalam Perspektif Pancasila Pada Era Revolusi Industri 4.0,” Jurnal Jurisprudence 9, no. 1 (September 18, 2019): 90, https:// doi.org/10.23917/jjr.v9i1.8091. 


\section{Definition, Scope, and Legal Basis of Islamic Economic Law}

Islamic Economic Law or figh muamalah consists of two words namely figh which etymologically comes from the sentence الفهـ (understanding) like the words فَقَّْهْتُ الدَّرََّ (I understand the lesson), whereas according to the terminology of figh, it means the knowledge of Islamic shari'a laws related to the actions of adults and clear headed taken from detailed propositions. The term figh in its writing such as fiqhi, fiqih, fiqh, and fikih, but in this paper the term used is "fikib" or "fiqh" in accordance with Indonesian and Arabic writing.

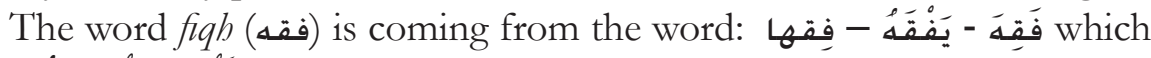

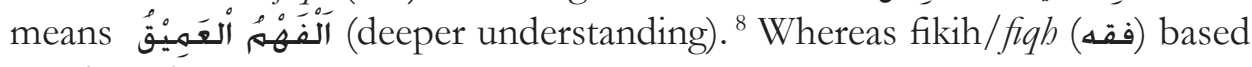
on ulama is:

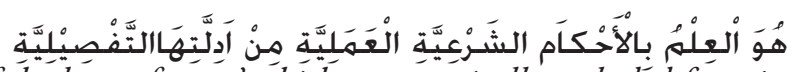
"Figh is the knowledge of the laws of syara" which are practically excluded from its propositions in detail."

As well as the word fikih/fiqh (فقد) in the dictionary of Al-Munawnir, fiqh (فقه) means know, understand, and simply fiqh may means know and understand. ${ }^{10}$ Other terms for figh defined as the religion that God created for human kind which complement the laws of religion linked to words, deeds, alliances, and more. While according to the jumbur fuqaba, fiqh is defined as the knowledge that explains the laws of syara' derived from the elaborate arguments of ta才》ili which are the specific laws taken through ijtihad. ${ }^{11}$ Other sources stated that fiqh according to the common fuqaha knowledge is "all the laws of syara" taken from the Book of Allah and the sunnah of the Messenger of Allah. by way of deepening understanding and ownership, which are through ijtihad and istinbat. Fiqh is a basic knowledge of Islamic teachings including Islamic law which is understood and practiced in Indonesia. By understanding about fiqh, means diminishing the debate of the caliphate, which means that tolerance in the caliphate is being honoured.

8 Supardin, Fikih Peradilan Agama Di Indonesia: Rekonstruksi Materi Perkara Tertentu (Alauddin University Press, 2014), 29; Minhajuddin, Pengembangan Metode Ijtihad Dalam Perspektif Fikih Islam (Makassar: UIN Alauddin Makassar, 2004), 1; Aḥmad bin Muhammad al-Makrī al-Fayūmī, Al-Miṣbah al-Munīr, vol. 2 (Beirut: Maktabah 'Ilmiah, n.d.),402.

9 Manna’ al-Qaththan, Al-Tasyr’’ Wa al-Fiqh Fì al-Islämi Tärīkhà Wa Manhajā (Beirut: Muassasah alRisālah, 1982), 121.

10 Ahmad Warson Munawwir, Kamus AlMunawwir : Arab-Indonesia Terlengkap (Pustaka Progressif, 2002), 1067.

11 M. Hasbi Ash Shiddieqy, Pengantar Ilmu Fiqh (Jakarta: Bulan Bintang, 1991), 17. 
Then, Muamalab is etymologically a type of masdar from the word عمل which means to act with one another, know one another and act with one another. ${ }^{12}$ Whereas terminologically, muamalab means all religious rules which govern relationships between human beings. For example, in the matter of buying and selling, debt, trade cooperation, unionization, cooperation in the cultivation of land and renting. ${ }^{13}$ The above understanding, gives an understanding that this muamalah issue is regulated as well as possible so that humans can meet their needs without giving harm to others.

The development of the types and forms of muamalah done by humans in the past until today is in line with the development of human needs and knowledge. ${ }^{14}$ Therefore it can be found in diverse ethnic groups, types and forms of muamalah, which essentially doing social interactions with one another in an effort to meet their needs. As the word of Allah Almighty in Q.S al-'Isra' [17]: 84 saying that

"Say, "Each works according to his manner, but your Lord is most knowing of who is best guided in way."

Thus, the problem of muamalah is an essential matter and becomes an important goal of the Islami to improve human life. Thus, the Shari'a muamalah is sent down by Allah SWT globally and publicly, by presenting various principles and norms that can guarantee the principle of justice in social interaction among human beings. The scope of Islamic Economic Law (fiqh muamalah) is divided into two, which are: ${ }^{15}$ First, Muamalah which legal provisions are directly come from the Qur'an and Hadith. This type of muamalah is in the form of marriage, and the scope of figh muamalab consists of two; such as divorce, iddah, reconciliation, inherited wealth. The same goes for the ban on alchohol, pigs, dogs and usury. Therefore, the transactions in this form are not allowed. Likewise in criminal acts, such as theft and adultery. God has firmly established the set of law regarding those matters above, because of those matters will be difficult for humans to find the ultimate truth due to impulses and the whispers of Satan. As the word of Allah in Q.S al-Isra [17]: 53

"And tell My servants to say that which is best. Indeed, Satan induces [dissension] among them. Indeed Satan is ever, to mankind, a clear enemy."16

12 Rachmat Syafei, Fiqih Muamalah (Bandung: CV Pustaka Setia, 2006), 60.

13 Nasrun Haroen, Fiqh Muamalah (Bandung: Pustaka setia, n.d.), 12.

14 Sri Sudati, Fikih Muamalah Kontemporer (Medan: UIN Sumatera Utara, 2018), 7.

15 Suhendi, Figh Muamalah, 5.

16 Kementerian Agama RI, Al-Qur'an Dan Terjemabnya (Bekasi: Mulia Abadi, 2015), 287. 
Based on the above verse, it appears that humans will easily turn away and disputes when they are influenced by lust and whispering of devils. Therefore, God has established several legal provisions. Likewise, the provisions stipulated by Allah to do good to both parents even though they have different aqidah / beliefs.

Second, The provisions of the law are not directly from the Qur'an and the hadith, but are based on the laws derived from the result of ijtihad of the fuqaha which refer to the general rules and principles in accordance with syara' law. The types of muamalah will be influenced by social situations and conditions. This can be seen in the practice of buying and selling in supermarkets, where the buyer is given the freedom to choose the wanted item and bring it to the cashier to check the price of the goods, buying and selling like this happens by handing over money and goods without any clear words (ijab and qabul). ${ }^{17}$ The practice of buying and selling is understood from the word of Allah in Q.S al-Nisa': 4:

"O you who have believed, do not consume one another's wealth unjustly but only [in lawful] business by mutual consent. And do not kill yourselves [or one another]. Indeed, Allah is to you ever Merciful."18

The above verse implies the ability to conduct trades that happen because of the two parties agreement within the transaction, are done easily without any difficulties and bring benefits to fellow human beings. Thus Allah has revealed His mercy to humans, God does not want His servants to be in hard situation, and God gives wide opportunity to humans to develop various creations in the field of muamalah in meeting the needs of life for the achievement of happiness in the world and the hereafter. In regard to the explanation of the type of muamalah above therefore it shows that the specific discussion is about the the provisions in the field of engagement and agreements for the fulfillment of needs covering all aspects of activities in the economic field. In this economic activity, the scope of the discussion can be divided into two parts. The first part discusses the procedure for its implementation (which is adabiyab). Such as: problem igat (consent and proposal or ijab qabul). The second part discusses the forms of transactions in the economic field (which are madiyah). Such as: buying and selling, leasing, wakalah, biwalah, wadi'ah and others. ${ }^{19}$

17 Sudati, Fikih Muamalah Kontemporer, 9.

18 Kementerian Agama RI, Al-Qur'an Dan Terjemahnya, 83.

19 Sudati, Fikih Muamalah Kontemporer, 11. 


\section{The Fundamental of Islamic Economic Law}

The sources of figh muamalah generally come from two main sources, namely the proof of naqli of the Koran and al-Hadith, and the argument of aqli in the form of reason/sense (ijtibad).$^{20}$ First, Al-Quran is the book of Allah revealed to the Prophet Muhammad. in Arabic which has the message of righteousness and progress of human beings, which applies in this world and the hereafter. Al-Quran is the main reference of Muslims, including legal issues and legislation. In general, it has been agreed that the commands in the Qur'an should not be changed. Examples of the verses of al-Qur'an which become the source of law regarding economic activities include those of trade, in surah al-Rahman [55]: 9 "And establish weight in justice and do not make deficient the balance."21

Second, Al-Hadith, is all that is done by the Messenger of Allah (may peace be upon him). Al-Hadith is the second source of fiqih after the Qur'an which is apply and binding to all Muslims. ${ }^{22}$ Third, Ijtihad (Ijma' dan Qiyas). Ijma' is the mujtabid agreement on a shar'i law in a period after the death of the Prophet. A syar'i law in order to be called as ijma' the determination of the agreement must be carried out by all mijtahid, although there is another opinion which states that ijma' can be formed only by the agreement of the majority of mujtabid. ${ }^{23}$ Whereas qiyas is the method for applying the laws in new cases that are not contained in na (al-Qur'an or al-Hadith), by synchronizing to new cases that are already contained in $n a{ }^{24}$ Above are some of the explanations regarding the basics of fiqih muamalah. If there is a religious activity that is not yet mentioned in the Qur'an and the hadith then the mujtabid performs the ijtibad using the legal framework in the context of na.

\section{History of Islamic Economy}

During his period of service, the Messenger of Allah (Rasulullah) had established the legal basis to govern human behavior in carrying out economic activities. The economic system applied by the Prophet rooted in Quranic principles. At that time al-Qur'an was a source of reference of the Prophet Muhammad in establishing rules governing human life in all aspects of life including economic behavior. ${ }^{25}$ In the trade sector, the Prophet Muhammad has made rules that must

20 Ma'ruf Abdullah, Hukum Kenangan Syariah (Yogyakarta: Aswaja Pressindo, 2016), 29.

21 Kementerian Agama RI, Al-Qur'an Dan Terjemahnya, 531.

22 Abdullah, Hukum Kenangan Syari'ah, 33-34.

23 Syamsul Anwar, Hukum perjanjian syariah: studi tentang teori akad dalam fikih muamalat (Jakarta: RajaGrafindo Persada, 2007), 15-34.

24 Abdullah, Hukum Keuangan Syariah, 37.

25 Euis Amalia, Kebijakan Ekonomi Di Masa Khulafaurrasyidin (Jakarta: Pustaka Asatruss, 2013), 4. 
be implemented by humans, for example a prohibition on buying and selling containing elements of deception, prohibiting usury, and so on. As Head of State, sometimes the prophet conducts direct supervision on buying and selling activities in the market. ${ }^{26}$ Buying and selling activities implemented by the Prophet is a free market system in which prices are given directly to the parties involved in buying and selling activities.

The Islamic economic system at the time of caliphs was actually completely different from the economic system carried out at the time of the Prophet Muhammad when he was still the head of state. At the first caliph, Abu Bakr ash-Shiddiq (51 $\mathrm{SH}-13 \mathrm{H} /$ 537-634 AD), he faced many problems in his leadership including facing apostates who did not want to pay zakat. After successfully dealing with these problems, Abu Bakr rebuilt the Baitul Mal and continued the distribution of assets for the people, as the Prophet Muhammad. has done previously. ${ }^{27}$ During the reign of Umar ibn Khattab, he was seen as the caliph with the most innovations. In managing state property, Umar always consulted with his friends. The policies undertaken by Umar included not distributing Baitul Mal assets at once, but gradually distributing them. During the Umar era, the law of trade underwent improvements to create a good economy. Umar reduced some of the tax burden on some goods..$^{28}$

In the period of Usman administration, he experienced many problems, perhaps because at the time of his appointment as caliph he was around 70 years old. Usman ruled for 12 years. During the first 6 years of Usman's reign he was able to properly organize the government, especially overseeing trade, natural resources and government administration. Usman bin Affan, was a generous wealthy man in distributing state assets. Usman did not spend the treasury of Baitul Mal wastefully, he just wanted to approve the spending of Baitul Mal for very emergency purposes only. During the reign of Ali bin Abi Talib $(23 \mathrm{SH}-40 \mathrm{H}$ / 600-661M), he was known as a very simple caliph. ${ }^{29}$ During Ali's reign, Ali had to resolve the conflict which was unresolved during the Usman government. $\mathrm{He}$ must manage the economy carefully. Ali was directly out of the list of Baitul Mal aid recipients, in addition to that he also provided 5,000 dirhams of aid funds annually to the state. Ali also printed his own currency as a substitute for the dinar currency from Rome and the dirham from Persia for the survival of his country. 26 Amalia, Kebijakan Ekonomi 5.

27 Pusat Pengkajian dan Pengembangan Ekonomi Islam, Ekonomi Islam (Yogyakarta: Rajawali Pers, 2013), 99.

28 Pusat Pengkajian dan Pengembangan Ekonomi Islam, 101.

29 Rozalinda, Ekonomi Islam: Teori Dan Aplikasinya Pada Aktivitas Ekonomi (Depok: Rajawali Pers, 2017), 51. 
${ }^{30}$ Ali was known as a smart and simple caliph.

The concept of Industry 4.0

The fourth industrial revolution stimulates the advances of science and technology, in which the Internet of Things (IoT) and its supporting technologies serve as backbones for Cyber-Physical Systems (CPS) and smart machines are used as the promoters to optimize production chains. Such advancement goes beyond the organizational and territorial boundaries, comprising agility, intelligence, and networking. ${ }^{31}$ The concept of "Industry 4.0" was first used in public at the Hannover Messe industrial exhibition in the city of Hannover, Germany in 2011. From this view the idea of "Industry 2.0" and "Industry 3.0" has just emerged, previously known as the "Technological Revolution" And the "Digital Revolution". All revolutions were carried out using the previous revolution as a basis. Industry 2.0 will not appear as long as we still rely on muscle, wind and air for production. Industry 3.0 starts updating production lines with computers and robots. So, industry 4.0 also definitely uses computers and robots as a foundation. ${ }^{32}$ The things that have emerged in our computer world lately are as follows.

First, the most noticeable progress is the internet. All computers are connected to a shared network. Computers are also getting smaller so that it can become our fist, so we have a smartphone. Not only are we connected to the giant network, we are always connected to the giant network. This is the first part of the fourth industrial revolution: "Internet of Things" when the computers in the factory are connected to the internet, when every problem in the production line can be immediately known when it is also by the factory owner, wherever the owner is. Second, technological advances have also created millions of new sensors, and millions of ways of utilizing information obtained from these sensors that are asking for help 24 hours a day. This information even concerns the performance of its human employees. For example, companies can now track all and every employee while in the factory. From this movement, it can be seen, for example, if these employees spend too much time in one section, so that part needs to be improved. Because of this vast variety and amount of new data, this aspect is often called Big Data.

30 Amalia, Kebijakan Ekonomi Di Masa Khulafaurrasyidin, 6.

31 Yongxin Liao et al., "The Impact of the Fourth Industrial Revolution: A Cross-Country/Region Comparison,” Production 28 (2018): 28, https://doi.org/10.1590/0103-6513.20180061.

32 Iwan Fahri Cahyadi, "Peranan Sistem Informasi Akuntansi Dan Tantangan Profesi Akuntan Di Era Revolusi Industri 4.0 (Sebuah Studi Fenomenologi)," AKTS AR: Jurnal Akuntansi Syariah 2, no. 1 (June 21, 2019): 69, https://doi.org/10.21043/aktsar.v2i1.5497. 
Third, related to the first and second, is Cloud Computing. ${ }^{33}$ Cloud Computing is a model allows the use of resources (server,networks, storage, applications, services, etc.) together that can be easily configured and minimize interaction with service providers. ${ }^{34}$ Complicated calculations still require a large sophisticated computer, but because it is connected to the internet, because there is a lot of data that can be sent via the internet, all of these calculations can be done elsewhere, approved at the factory. So, a company that has three factories in different countries only needs to buy a supercomputer to process the data needed simultaneously to buy the factory. It is no need to buy three supercomputers to do it fully.

\section{The Challenges of Islamic Economic Law in the Industrial Revolution 4.0}

Islam emerged as a new power in the 7 th Century $\mathrm{AD}$, following the collapse of the Roman empire. The emergence was marked by the development of a new outstanding civilization. Culture, science, and technology as well as other social lives including the economy were developed in an amazing and rapid manner. Historical fact, actually shows that Islam is a comprehensive system of life, which regulates all aspects, in social, economic, and political as well as spiritual life. Economics as an aspect of life, of course, is also governed by Islam. This can be understood, as a perfect religion, it is impossible that Islam is not equipped with economic systems and concepts. A system that can be used as a guide for people in carrying out economic activities. A system that has been outlined in the Qur'an and al-Sunnah.

At present, the economic life has become the standard of individual and collective life of a country and nation. The superiority of a country is measured based on the level of economic progress and the measure of the degree of success tends to be very materialistic. Therefore, economics is very important for the life of a nation. Prominent economics scholars like Marshal states that world life is controlled by two great powers, namely economics and faith (religion). ${ }^{35}$ In the

33 Sari Utami, "Eksistensi Perkembangan Perekonomian Perempuan di Era Digitalisasi," AN-NIS A : Jurnal Studi Gender dan Anak 12, no. 1 (September 15, 2019): 597, https://doi.org/10.30863/annisa. v12i1.454.

34 Muhammad Imam Ghozali, Wibowo Harry Sugiharto, and Zaenal Afifi, "Cloud Computing Sebagai Strategi Optimasi Perluasan Target Pasar Usaha Kecil Menengah Dalam Menghadapi Revolusi Industri 4.0," Jurnal Mantik Penusa 3, no. 1.1 (August 30, 2019): 106, http://e-jurnal.pelitanusantara.ac.id/index. $\mathrm{php} / \mathrm{mantik} /$ article/view/590.

35 Mahmud Abu Su'ud, Kbuthut Ra'isiyyah Fi al-Iqtishad al-Islamiyy (Kuwait: Maktabat al-Manar al-Islamiyyah, 1968), 56. This book cites the definition of economics according to Marshal, namely the science that teaches humans about daily life; discuss individual and collective activities to meet their material needs and ways to use them to achieve their welfare. 
modern times there has been a rapid development in the economic field. ${ }^{36}$ This can be seen from the cities that developed into centers of trade, exchange of goods, monetary economic activities, and banking. The middle class makes an effort to rise from adversity by developing a certain freedom. This freedom is related to the basic conditions of life.

Especially in the last few years, sharia-based economic institutions are increasingly on the national economy. They were born following a prolonged crisis as a result of the failure of the capitalist monetary system in Indonesia. Since the establishment of Bank Muamalat as a bank pioneer that used the Shari'ah system in 1991, there are now many sharia banks, both purely using the system or only using it at the stage of opening the Shari'ah Business Unit or shari'ah business division. The history of the development of sharia banking in Indonesia formally began with the MUI workshop on banking in 1990, which was then followed by the issuance of Law No. 7 of 1992 of The Republic of Indonesia concerning Banking which accommodates bank activities with the principle of profit sharing. The establishment of Bank Muamalat Indonesia (BMI), which used a profit sharing pattern in 1992, marked the beginning of the era of the dual banking system in Indonesia.

Despite the development of the global economy and increasing public interest in the Islamic economy and banking, the Islamic economy faces various problems and great challenges. There are at least five problems and challenges facing the Islamic economy in this modern era. First, there is still a lack of qualified Islamic economics experts who master the modern economics and sharia studies in an integrative way. Second, a test of the credibility of the economic and financial system. Third, the regulatory, legal and policy instruments, both on a national and international scale are still inadequate. Fourth, the role of the government, both executive and legislative, is still low on the development of sharia economics, due to their lack of understanding and knowledge of Islamic economics.

Because of these challenges, the author believes that the development of the Islamic economic system in Indonesia, in the future must take further steps or development strategies to implement the Islamic economic system more optimally, including: a) There must be a representative who promote the Islamic economic system, especially in the politics; b) Carrying out intensive seminars, discussions, gatherings and scientific forums both regionally, nationally and internationally; c) Drafting the provisions of the Islamic economic system; d) Promoting the formation of shariah communication forums; and e) Improving the quality

36 Muhammad Syafi'i Antonio, Bank Syariab: Dari Teori Ke Praktik (Jakarta: Gema Insani, 2001), 18. 
of Human Resources (HR) with a focus on education and sociality movements carried out optimally and appropriately.

\section{Conclusion}

Muamalah as a result of understanding Islamic law in its formation contains of human intellectual properties. Therefore, at the same time there are elements of revelation and intellectual elements within muamalah, aimed at bringing the unity of the people and upholding the principles of justice. Basically, muamalah is allowed as long as there is no verses of Qur'an of hadis that declare it as illegitimate/ haram. The general character of the economy in the period of Prophet Muhammad was the high commitment to ethics and norms and the great attention to justice and wealth distribution. Economic efforts must be carried out ethically within the framework of Islamic sharia. Islamic Economic Law which still seems classic, has challenges in facing technological advancements in the 4.0 industrial revolution. It will certainly affect the progress of the Islamic economy in the society. Indeed, the Islamic economic system is very prospective, not only for now but for thethe future, but at the same time is also a challenge for Muslims to continuously conduct studies, evaluations, and find solutions to the theories, concepts, and implementation of Islamic economics in various models and forms.

\section{Bibliography}

Abdullah, Ma'ruf. Hukum Kenangan Syariah. Yogyakarta: Aswaja Pressindo, 2016.

Abu Su'ud, Mahmud. Khutbut Ra'isizyah Fi al-Iqtishad al-Islamiyy. Kuwait: Maktabat al-Manar al-Islamiyyah, 1968.

Amalia, Euis. Kebijakan Ekonomi Di Masa Khulafaurrasyidin. Jakarta: Pustaka Asatruss, 2013.

Antonio, Muhammad Syafi'i. Bank Syariah: Dari Teori Ke Praktik. Jakarta: Gema Insani, 2001.

Anwar, Syamsul. Hukum perjanjian syariah: studi tentang teori akad dalam fikih muamalat. Jakarta: RajaGrafindo Persada, 2007.

Ash Shiddieqy, M. Hasbi. Pengantar Ilmu Fiqh. Jakarta: Bulan Bintang, 1991.

Cahyadi, Iwan Fahri. "Peranan Sistem Informasi Akuntansi Dan Tantangan Profesi Akuntan Di Era Revolusi Industri 4.0 (Sebuah Studi Fenomenologi)." AKTS AR: Jurnal Akuntansi Syariah 2, no. 1 (June 21, 2019): 69-82. https:// doi.org/10.21043/aktsar.v2i1.5497. 
Fayūmī, Aḥmad bin Muḥammad al-Makrī al-. Al-Mișbah al-Munìr. Vol. 2. Beirut: Maktabah Ilmiah, n.d.

Ghozali, Muhammad Imam, Wibowo Harry Sugiharto, and Zaenal Afifi. "Cloud Computing Sebagai Strategi Optimasi Perluasan Target Pasar Usaha Kecil Menengah Dalam Menghadapi Revolusi Industri 4.0.” Jurnal Mantik Penusa 3, no. 1.1 (August 30, 2019). http://e-jurnal.pelitanusantara.ac.id/index.php/ mantik/article/view/590.

Haroen, Nasrun. Fiqh Muamalah. Bandung: Pustaka setia, n.d.

Hidayah, Khoirul. "Model Pembiayaan Pendaftaran Merek Bagi Pengusaha Kecil Menengah Dengan Melalui Akad Bai' Al Istishna'.” Jurisdictie: Jurnal Hukum Dan Syariah 10, no. 2 (2019). http://dx.doi.org/10.18860/j.v10i2.8303.

Idayanti, Soesi, Suci Hartati, and Toni Haryadi. "Pembangunan Hukum Bisnis Dalam Perspektif Pancasila Pada Era Revolusi Industri 4.0.” Jurnal Jurisprudence 9, no. 1 (September 18, 2019): 90-101-101. https://doi.org/10.23917/jjr. v9i1.8091.

Kementerian Agama RI. Al-Qur'an Dan Terjemahnya. Bekasi: Mulia Abadi, 2015.

Liao, Yongxin, Eduardo Rocha Loures, Fernando Deschamps, Guilherme Brezinski, André Venâncio, Yongxin Liao, Eduardo Rocha Loures, Fernando Deschamps, Guilherme Brezinski, and André Venâncio. "The Impact of the Fourth Industrial Revolution: A Cross-Country/Region Comparison." Production 28 (2018). https://doi.org/10.1590/0103-6513.20180061.

Minhajuddin. Pengembangan Metode Ijtihad Dalam Perspektif Fikih Islam. Makassar: UIN Alauddin Makassar, 2004.

Munawwir, Ahmad Warson. Kamus AlMunamwir : Arab - Indonesia Terlengkap. Pustaka Progressif, 2002.

Pusat Pengkajian dan Pengembangan Ekonomi Islam. Ekonomi Islam. Yogyakarta: Rajawali Pers, 2013.

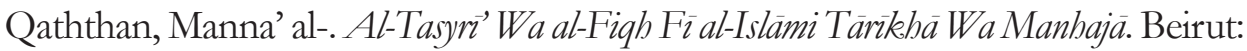
Muassasah al-Risālah, 1982.

Qonita, Nuha. "Positioning Islamic Legal Theory in the Development of Islamic Finance." Jurisdictie: Jurnal Hukum Dan Syariah 10, no. 1 (2019). http:/ / dx.doi. org/10.18860/j.v10i1.7034. 
Rozalinda. Ekonomi Islam: Teori Dan Aplikasinya Pada Aktivitas Ekonomi. Depok: Rajawali Pers, 2017.

Sudati, Sri. Fikih Muamalah Kontemporer. Medan: UIN Sumatera Utara, 2018.

Suhendi, Hendi H. Fiqh Muamalah: Membahas Ekonomi Islam Kedudukan Harta, Hak Milik, Jual Beli, Bunga Bank Dan Riba, Musyarakah, Ijarah, Mudayanah, Koperasi, Asuransi, Etika Bisnis Dan Lain- Lain. Jakarta: PT RajaGranfindo Persada, 2002.

Supardin. Fikib Peradilan Agama Di Indonesia: Rekonstruksi Materi Perkara Tertentu. Alauddin University Press, 2014.

Suwardana, Hendra. "Revolusi Industri 4. 0 Berbasis Revolusi Mental." JATI UNIK: Jurnal Ilmiah Teknik dan Manajemen Industri 1, no. 2 (April 18, 2018): 109-18. https://doi.org/10.30737/jatiunik.v1i2.117.

Syafei, Rachmat. Fiqih Muamalah. Bandung: CV Pustaka Setia, 2006.

Syamsudin, Muhammad. "Revolusi Industri 4.0 Dan Perkembangan Akad Muamalah." Accessed May 21, 2020. https://islam.nu.or.id/post/read/92425/revolusiindustri-40-dan-perkembangan-akad-muamalah.

Utami, Sari. "Eksistensi Perkembangan Perekonomian Perempuan di Era Digitalisasi." AN-NIS A : Jurnal Studi Gender dan Anak. 12, no. 1 (September 15, 2019): 596-609. https://doi.org/10.30863/annisa.v12i1.454. 